\title{
ZFYVE9 Gene
}

National Cancer Institute

\section{Source}

National Cancer Institute. ZFYVE9 Gene. NCI Thesaurus. Code C24569.

This gene is plays a role in signal transduction and is involved in Alzheimer's disease. 